\title{
TANGGUNG JAWAB NOTARIS AKIBAT PEMBUATAN AKTA NOMINEE YANG MENGANDUNG PERBUATAN MELAWAN HUKUM OLEH PARA PIHAK
}

\author{
THE NOTARY RESPONSIBILITY ON NOMINEE DEED WHICH \\ CONTAIN AGAINST THE LAW ACTIONS BY THE PARTIES
}

\author{
Endah Pertiwi \\ Magister Kenotariatan Universitas Brawijaya \\ Email: endahpertiwi95@gmail.com \\ Naskah diterima : 11/07/2018; direvisi : 27/07/2018; disetujui : 27/07/2018
}

\begin{abstract}
The Nominee Agreement in the agreement law in Indonesia is categorized as an agreementwhich indicates the creation of legal smuggling. This Agreement has not yet been regulated in the Civil Code but in reality it grows and develops in society, this agreement also fall into the category of unnamed agreement (Innominat Contract). This journal is a normative juridical study with the approach of statute, case approach and conceptual approach, this study aims to analyze and explain the Responsibility of Notary to the deeds of the law carried out by the parties in the deed of Nominee, from the description above, the result of this study is the Notary can be held accountablity to the making of the deed which is against the civil, Criminal, and also administrative laws. Because the nominee is not regulated, it aims to construct the law to overcome the unlawful acts committed in the nominee deed made by the Notary by using the Legal System Theory According to Lawrence Meir Friedman regarding the legal structure that should be more tightened security by MPD, MPW even up to MPN, / legal substance should be the clarity of norms, the existence of Nominee ban, to the provision of strict sanctions, the last about the legal culture that must be adapted to the culture in Indonesia, increase public awareness, even if the need to socialize about the nominee to the public.
\end{abstract}

\section{Keywords: Nominee Agreement, Notary's Responsibility, Act Against The} Law, Law Construction.

\begin{abstract}
Abstrak
Perjanjian Nominee dalam hukum perjanjian di Indonesia dikategorikan sebagai perjanjian yang berindikasi menciptakan penyelundupan hukum. Perjanjian ini belum diatur dalam KUHPerdata namun dalam kenyataannya tumbuh dan berkembang dalam masyarakat,perjanjian ini juga masuk dalam kategori jenis perjanjian tidak bernama (Innominat Contract). jurnal ini adalah penelitian yuridis normatif dengan metode pendekatan Perundang-Undangan, pendekatan kasus dan pendekatan konseptual, penelitian ini bertujuan untuk menganalisa dan menjelaskan mengenai Tanggung Jawab Notaris terhadap perbuatan melawa hukum yang dilakuka para pihak dalam akta Nominee, dari uraian diatas maka hasil dari penelitian ini adalah Notaris dapat dimintakan pertanggungjawaban terhadap pembuatan akta yang merupakan perbuatan melawan hukum secara Perdata, Pidana, dan juga secara administrasi. Karena tidak diaturnya nominee maka penulis bertujuan mengkonstruksikan hukum untuk menanggulangi perbuatan melawan hukum yang dilakukan dalam akta nominee yang dibuat oleh Notaris dengan menggunakan Teori Sistem Hukum Menurut Lawrence Meir Friedman mengenai
\end{abstract}


struktur hukum yang harus lebih memperketat keamanan oleh MPD, MPW bahkan sampai pada MPN, isi/subtansi hukum harus adanya kejelasan norma, adanya pelarangan Nominee, sampai pada pemberian sanksi yang tegas, yang terakhir mengenai budaya hukum yang harus disesuaikan dengan budaya di Indonesia, peningkatan kesadarab masyarakat, bahkan jika perlu diadakannya sosialisasi tentang nominee kepada masyarakat.

\section{Kata Kunci : Perjanjian Nominee, Tanggung Jawab Notaris, Perbuatan Melawan Hukum, Konstruksi Hukum.}

\section{PENDAHULUAN}

Berdasarkan Pasal 1 Undang-Undang Nomor 30 Tahun 2004 tentang Jabatan Notaris sebagaimana telah diubah dengan Undang-undang Nomor 2 Tahun 2014 tentang Perubahan Atas Undang-Undang Nomor 30 Tahun 2004 tentang Jabatan Notaris (selanjutnya disebut UUJN) dinyatakan bahwa "Notaris adalah Pejabat umum yang berwenang untuk membuat akta otentik dan kewenangan lainnya sebagaimana dimaksud dalam Undangundang ini". Kewenangan tersebut lebih jelas disebutkan dalam Pasal 15 ayat (3) UUJN bahwa :

"Notaris berwenang membuat akta autentik mengenai semua perbuatan, perjanjian, dan penetapan yang diharuskan oleh peraturan perundang-undangan dan/atau yang dikehendaki oleh yang berkepentingan untuk dinyatakan dalam akta autentik, menjamin kepastian tanggal pembuatan akta, menyimpan akta, memberikan grosse, salinan, dan kutipan akta, semuanya itu sepanjang pembuatan Akta itu tidak juga ditugaskan atau dikecualikan kepada pejabat lain atau orang lain yang ditetapkan oleh Undangundang."

Dalam perkembangan dunia usaha dan bisnis saat ini, para pelaku usaha semakin giat bersaing, banyaknya kekayaan alam yang terkandung ditanah air ini serta peluang untuk mengembangkan usaha yang begitu besar, menggugah kreatifitas para investor dan pengusaha asing untuk berwirausaha di Indonesia.

Berdasarkan konsep dasar UndangUndang Nomor 5 Tahun 1960 tentang
Peraturan Pokok-pokok Agraria bahwa "bumi, air dan kekayaan alam yang terkandung didalamnya digunakan untuk sebesar besarnya kemakmuran rakyat", yang dimaksud disini adalah rakyat asli Indonesia, tujuannya agar mensejahterakan untuk mencapai kemakmuran bagi rakyat Indonesia terhadap kepemilikan tanah dan juga hasil tanah. Sebagaimana disebutkan dalam Undang-Undang Pokok Agraria di dalam ketentuan Asas Kebangsaan atau Asas Nasionalitas terdapat dalam Penjelasan Umum Undang-Undang Nomor 5 Tahun 1960 tentang Peraturan Dasar Pokok Agraria (UUPA) bahwa Asas Nasionalitas yang memberikan batasan dalam lalu lintas tanah ini yang mengakibatkan terdapat perlakuan yang berbeda atas benda tanah dan benda bukan tanah.

Dalam Undang-Undang Pasal 5 ayat (2) Undang-Undang Investasi mengatur bahwa, kecuali diatur sebaliknya, investor asing dapat melaksanakan investasi asing di Indonesia dengan mendirikan perusahaan investasi asing berdasarkan UU No. 40 Tahun 2007 tentang Perseroan Terbatas dan peraturan pelaksanaannya. Perusahaan investasi asing juga dikenal sebagai PT Penanaman Modal Asing. Investasi asing di Indonesia dalam bentuk PT dapat dilakukan dengan kepemilikan saham pada saat pendirian perusahaan atau pembelian saham dalam perusahaan yang sudah didirikan baik PT maupun PT PMA(Penanaman Modal Asing), namun harus melengkapi dokumen perizinan persyaratan pendirian perusahaan, syarat tersebut secara hukum harus diperhatikan oleh investor asing sebelum melakukan kegiatan investasi, dalam Pasal 33 ayat (1) 
Undang-undang Nomor 25 Tahun 2007 tentang Penanaman Modal melarang adanya pinjam nama atas kepemilikan saham karena merupakan perbuatan yang sangat jelas melanggar pasal tersebut diatas. Hal ini dikarenakan tidak diperbolehkannya Orang asing untuk menanam modal/ investasi dalam bidang usaha yang tertutup.

Kondisi dari adanya pembatasanpembatasan dan sulitnya persyaratan yang diatur oleh pemerintah terhadap Orang Asing tersebut diatas menjadikan para pihak yang berkepentingan mencari suatu cara untuk melakukan segala cara untuk memiliki tanah lebih dari Hak Pakai yang diberikan agar lebih leluasa dalam menggunakan tanahnya karena jelas hak milik merupakan hak tertinggi, terkuat dan turun temurun, terhadap kepemilikan saham agar tetap dapat berinvestasi di Indonesia terhadap perusahaan yang tertutup. Cara yang kemudian digunakan untuk memenuhi kebutuhan usaha investor asing yaitu dengan melakukan pembuatan Akta Nominee antara Orang Asing dengan WNI, yaitu dengan mempergunakan nama orang lain yang merupakan WNI sebagaimana ditunjuk sebagai Nominee untuk didaftarkan sebagai pemilik atas tanah tersebut.

Perjanjian Nominee dalam hukum perjanjian di Indonesia dikategorikan sebagai perjanjian yang berindikasi menciptakan penyelundupan hukum. Perjanjian ini belum diatur dalam KUHPerdata namun dalam kenyataannya tumbuh dan berkembang dalam masyarakat, perjanjian ini juga masuk dalam kategori jenis perjanjian tidak bernama.

Perjanjian nominee memiliki ranah yang cukup luas dalam penggunaannya karena didalam akta nominee itu sendiri terdiri atas kuasa, di Indonesia ini praktek dari perjanjian nominee masuk dalam ranah kepemilikan tanah dan juga terhadap kepemilikan saham, penanaman modal, pendirian PT dan segala bentuk kepemilikan dalam hukum perdata.

Terhadap perjanjian nominee biasanya dituangkan dalam bentuk akta oleh para pihaknya untuk memperkuat perjanjian tersebut yang dibuat dengan akta otentik, akta Nominee yang dibuat oleh Notaris dapat dikatakan sebagai suatu perbuatan melawan hukum yang juga dilakukan oleh para pihak dalam akta tersebut, karena perbuatan ini mengadung unsur melanggar ketertiban umum, perbuatan melawan hukum ini berbentuk penyelundupan hukum. Perbuatan ini juga jelas telah melanggar hukum dan ketentuan Undangundang yang berlaku karena akta tersebut dapat digunakan untuk mendapatkan tanah oleh Orang Asing, hal ini sangat jelas bahwa perbuatan tersebut dikatan sebagai perbuatan melawan hukum karena mengandung unsur-unsur dariperbuatan melawan hukum berdasarkan Pasal 1365 KUHPerdata.

Dalam kehidupan masyarakat saat ini banyak sekali kasus yang mengakibatkan Notaris dilaporkan atas dugaan keterlibatan Notaris dalam Akta Nomine, Keberadaan akta Nominee ini pada prakteknya berhubungan dengan prinsip keadilan sebagai perwujudan nilai-nilai tertentu ${ }^{1}$, yakni dengan melihat ada kepentingan dari para pihak dan juga keberadaan Notaris yang terlibat dalam pembuatan Aktanya yang juga tentunya menimbulkan kerugian-kerugian terhadap pihak yang bersangkutan jika akta ini tetap dibuat.

Dari latar belakang diatas maka timbul beberapa masalahan yang penulis akan bahas dalam penulisan ini yaitu:

Bagaimanakah tanggung jawab notaris terhadap perbuatan melawan hukum yang

${ }^{1}$ M. Yazid Fathoni, Konsep Keadilan Dalam Pengelolaan dan Pemanfaatan Sumber Daya Alam Menurut Undang-Undang Pokok Agraria Tahun 1960, Jurnal IUS (Hukum dan Keadilan), Vol. I, No. 1, April 2013, http://jurnalius.ac.id/ojs/index.php/jurnalIUS/article/ view/225/197, diakses tanggal 6 April 2018. Hlm. 46 
dilakukan para pihak dalam akta Nominee ? dan Bagaimanakah konstruksi hukum untuk menanggulangi perbuatan melawan hukum dalam akta Nominee yang dibuat Notaris?.

Untuk menganalisis dan menjawab perumusan masalah dalam artikel ini, penulis menggunakan penelitian normatif, dengan metode pendekatan Perundang-Undangan, pendekatan kasus dan pendekatan konseptual. Penelitian ini bertujuan untuk menganalisa dan menjelaskan mengenai Tanggung Jawab Notaris terhadap perbuatan melawan hukum yang dilakukan para pihak dalam akta nominee.

\section{PEMBAHASAN}

Tanggung Jawab Notaris Terhadap Perbuatan Melawan Hukum Yang Dilakukan Para Pihak Dalam Akta Nominee

Hukum Perjanjian sendiri diatur secara khusus dalam Buku ke III KUHPerdata, mengenai syarat sahnya perjanjian juga diatur dalam Pasal 1320 KUHPerdata sampai dengan Pasal 1337 KUHPerdata.

Dilihat dari syarat-syarat diatas adanya hubungan dan peran notaris dalam syarat tersebut, menurut pendapat penulis dari penjelasan diatas peran Notaris dalam Pasal 1320 yaitu :

a. Adanya kesepakatan, berarti bahwa penghadap yang terdiri dari para pihak yang akan membuat perjanjian haruslah saling sepakat antara keduanya ketika akan menghadap di hadapan Notaris. Mengandung makna bahwa para pihak yang membuat perjanjian telah sepakat atau ada penyesuaian kemauan atau saling menyetujui kehendak masingmasing yang dilahirkan oleh pihak dengan tiada paksaan kekeliruan dan penipuan. ${ }^{2}$ Karena pembuatan akta Notaris harus lah adanya kehadiran para pihak yang menghadap di hadapan

${ }^{2}$ Ridwan Syahran, Seluk Beluk dan Asas-asas Hukum Perdata, Alumni, Bandung: 2000, hlm.214
Notaris hal ini jelas diterangkan secara implisit dalam Pasal 39 UUJN yang menyimpulkan bahwa penghadap haruslah dikenal oleh Notaris ataupun diperkenalkan kepada Notaris.

b. Kecakapan Para Pihak, bahwa dalam syarat ini jelas sangat adanya peran Notaris karena Notaris wajib mengecek identitas para pihak yang akan tandatangan dalam akta dari Tanda Pengenal para pihak, hal ini jelas dinyatakan juga dalam Pasal 39 UUJN yangharussesuaidengan tandapengenal yang diberikan kepada Notaris pada saat pembuatan akta dan dijelaskan secara tegas dalam Akta.

c. Suatu hal tertentu, Syarat ketiga untuk sahnyaperjanjianyaitubahwaperjanjian harus mengenai suatu hal tertentu yang merupakan pokok perjanjian yaitu obyek perjanjian. ${ }^{3}$ Dalam hal ini peran Notaris tidak terlalu terlihat, karena Objek dari perjanjian biasanya dalam akta terletak pada isi Akta, Obyek dari perjanjian bebas asalkan bukan obyek yang dilarang oleh hukum. Beberapa persyaratan yang diatur dalam Pasal 1332-1334 KUHPerdata khususnya jika objek perjanjian tersebutberupabarang.

d. Suatu sebab yang halal, sebab dari pembuatan akta haruslah merupakan sebab yang halal, yang berarti bahwa Sebab atau causa adalah hal yang menyebabkan adanya perhubungan hukum berupa rangkaian kepentingankepentingan yang harus dipenuhi secara yang termaktub dalam isi perhubungan hukumitu. ${ }^{4}$ Sebabyanghalaldiaturdalam Pasal 1335-1337 KUHPerdata. Dalam Pasal 1335 KUHPerdata, dijelaskan bahwa yang disebut dengan sebab yang halal adalah:

1. bukan tanpa sebab

2. bukan sebab yang palsu

3. bukan sebab yang terlarang

\footnotetext{
${ }^{3}$ Hartono Hadi Soepapto, Pokok-pokok Perikatan dan Hukum Jaminan, Liberty, Yogyakarta, 1984, hlm.34.

${ }^{4}$ Wirjono Prodjodikoro, Azas-azas Hukum Perdata, Bale Bandung, Bandung: 1988, hlm. 67.
} 
Sesungguhnya dalam hal causa ini peran Notaris sangatlah perlu karena tidak setiap para pihak dalam membuat perjanjian sesuai dengan ketentuan perundang-undangan, dari beberapa para pihak pasti adanya kehendak para pihak yang menyalahi aturan maka dari itu peran Notaris disini haruslah meluruskan kehendak para pihak agar akta yang nantinya diterbitkan tidak cacat hukum.

Berdasarkan pasal 1319 KUHPerdata tersebut maka perjanjian dibedakan menjadi dua yaitu:

\section{Perjanjian Bernama (Nominate Contract)}

2. Perjanjian Tidak Bernama (Innominate Contract)

Salah satu contoh dari perjanjian Innominate dan yang akan penulis bahas dalam penulisan ini adalah perjanjian Nominee. Perjanjian innominate merupakan jenis perjanjian yang tidak dikenal dengan nama tertentu, namun tetap memiliki unsur-unsur yang sama dengan perjanjian pada umumnya, yaitu $:^{5}$

1) Adanya Unsur Kaidah Hukum, baik kaidah hukum perjanjian tertulis maupun tidak tertulis;

2) AdanyaUnsurSubjekHukum, yaitupara pihak dalam perjanjian;

3) Adanya Unsur Objek Hukum, yaitu pokok prestasi dalam perjanjian;

4) Adanya Unsur Kata Sepakat yang merupakan persesuaian pernyataan kehendakparapihakmengenaisubstansi dan objek perjanjian;

5) Adanya Unsur Hak Dan Kewajiban bagi para pihak sebagai akibat hukum yang timbul dari perjanjian.

Secara umum, penguasaan hak atas tanah diatur pada Pasal 41 dan 42 UUPA, yang diatur lebih lanjut dalam Peraturan PemerintahNomor 40 Tahun 1996 Tentang Hak Guna Usaha, Hak Guna Bangunan

\footnotetext{
${ }^{5}$ Ibid, hlm.4-5
}

dan Hak Pakai atas Tanah. Landasan hukum ketentuan pada Pasal 42 UUPA adalah Pasal 33 ayat (3)Undang-Undang Dasar 1945. Berdasarkan kewenangan yang diperoleh dari hak menguasai negara guna mengatur hubungan hukum antara subjek hukum dengan tanah, pemerintah dapat menentukan bermacam-macam hak atas tanah (Pasal 4 jo. Pasal 76 UUPA).

Berdasarkan Pasal 9 ayat (1) UUPA ditentukan pula bahwasannya Warga Negara Indonesia (WNI) yang dapat mempunyai hubungan sepenuhnya dengan bumi, air, dan ruang angkasa, hal ini berarti bahwa hanya Warga Negara Indonesia saja yang dapat mempunyai hak milik. Menurut UUPA, hak milik, hak guna usaha dan hak guna bangunan tidak dapat diberikan kepada orang atau investor asing. Bagi Orang Asing yang berkedudukan di Indonesia dan investor asing yang memiliki perwakilan di Indonesia dapat diberikan hak atas tanah berupa hak pakai.

Bagi Warga Negara Indonesia yang berpindah kewarganegaraan, atau Orang Asing yang karena warisan mendapatkan salah satu hak di luar hak pakai tersebut, selama satu tahun sejak perpindahan kewarganegaraannya itu, atau sejak hak tersebut diperolehnya, hak-hak tersebut harus dialihkannya, atau jika tidak dialihkan, akan berakibat hak atas tanahnya jatuh kepada negara, peralihan hak atas tanah batal demi hukum, demikian ketentuan yang diatur pada Pasal 21 ayat(2) jo. Pasal 30 ayat (2) dan Pasal 35 ayat (2) UUPA. Jadi, untuk Orang Asing sama sekali tidak terbuka kemungkinan untuk mendapatkan hak atas tanah dalam sistem hukum pertanahan kecuali hak pakai.

Dalam Undang-undang Nomor 25 tahun 2007 Tentang Penanaman Modal (selanjutnya disingkat UUPM) diperlakukan sama antara penanaman modal yang bersumber dari dana asing dengan modal yang bersumber dari dana 
dalam negeri. Berdasarkan ketentuan Pasal 22 ayat (1) kepada perusahaan dalam rangka penanaman modal menurut UUPM dapat diberikan HGU selama 95 (sembilan puluh lima)tahun dengan cara dapat diberikan diperpanjang di muka sekaligus selama 60 (enam puluh) tahun dan dapat diperbaharui selama 35 (tiga puluh lima), untuk HGB selama 80 (delapan puluh tahun) dengan cara diberikan dan diperpanjang untuk jangka waktu 50 (lima puluh) tahun dan 30 (tiga puluh) tahun serta Hak Pakai selama 70 (tujuh puluh) tahun dengan cara diberikan dan diperpanjang untuk jangka waktu 45 (empat puluh lima) tahun. ${ }^{6}$

Menanamkan modal di Indonesia bahwa investor asing harus terlebih dahulu meneliti daftar negatif investasi (DNI) yang berisi sektor usaha yang tertutup sama sekali terhadap semua bentuk penanaman modal, hanya tertutup untuk penanaman modal asing, dan yang masih terbuka dengan persyaratan tertentu. Sebagaimana diatur dalam Perpres No.76/2007 tentang kriteria dan persyaratan penyusunan bidang Usaha yang tertutup dan terbuka dengan persyaratan di bidang penanaman modal dan Perpres No. 77/2007 tentang daftar bidang usaha yang tertutup dan bidang usaha yang terbuka dengan persyaratan di bidang penanaman modal. Selain dari yang terdaftar, semua sektor terbuka untuk investor asing dengan kepemilikan hingga $100 \%$ persetujuan penanaman modal asing akan dikeluarkan oleh badan koordinasi penanaman modal (BKPM) di Jakarta. $^{7}$

Ketentuan lainnya mengenai penanaman modal dijelaskan mengenai sanksi dalam Pasal 33 dan Pasal 34 Undang-Undang Penanaman Modal untuk selanjutnya akan disebut dengan UUPM,

\footnotetext{
${ }^{6}$ Martin Roestami, Konsep-konsep Hukum Kepemilikan Properti Bagi Asing (dihubungkan dengan hukum pertanahan), Alumni, Bandung: 2011, hlm.118-120.

${ }^{7}$ Sri Adiningsih, Satu Dekade Pasca-Krisis Indonesia: Badai Pasti Berlalu, Kanisius, Jakarta, 2008, hlm.97
}

Pasal 33 ayat (1) UUPM menyebutkan bahwa penanam modal dalam negeri dan penanam modal asing yang melakukan penanaman modal dalam bentuk perseroan terbatas dilarang membuat perjanjian dan/ atau pernyataan yang menegaskan bahwa kepemilikan saham dalam Perseroan Terbatas untuk dan atas nama orang lain. Kemudian dalam Pasal 33 ayat (2) UUPM disebutkan bahwa dalam hal penanaman modal dalam negeri dan penanam modal asing membuat perjanjian dan/atau pernyataan sebagaimana dimaksud pada ayat (1), perjanjian dan/atau pernyataan itu dinyatakan batal demi hukum.

Pengertian Nominee dalam kamus hukum atau Black's Law Dictionary, adalah: seseorang ditunjuk bertindak atas pihak lain sebagai perwakilan dalam pengertian terbatas. Ini digunakan sewaktu-waktu untuk ditandatangani oleh agen atau orang kepercayaan. Tidak ada pengertian lain daripada hanya bertindak sebagai perwakilan pihak lain atau sebagai penjamin pihak lain. ${ }^{8}$

Nominee menurut Pasal 1 ayat (6) Peraturan Dirjen Pajak Nomor PER62/PJ.2009 tentang Pencegahan Penyalahgunaan Persetujuan Penghindaran Pajak Berganda, adalah orang atau badan yang secara hukum memiliki (legal owner) suatu harta dan/ atau penghasilan untuk kepentingan atau berdasarkan amanat pihak yang sebenarnya menjadi pemilik harta dan/ atau berdasarkan amanat pihak yang sebenarnya menikmati manfaat atau penghasilan.

Pada dasarnya konsep Nominee tidak dikenal dalam sistem hukum Eropa Kontiental atau Anglo-Saxon yang berlaku di Indonesia, di Indonesia baru mengenal Konsep Nominee dan sering digunakan dalam beberapa transaksi hukum khususnya perjanjian sejak bertambahnya jumlah investasi pihak asing di sekitar tahun 90-an, karena ketertarikannya

\footnotetext{
${ }^{8}$ Bryan A. Garner, Op.Cit, hlm 33
} 
penanam modal asing melakukan investasi di Indonesia dengan didasari pendapatan keuntungan yang cukup besar serta upah tenaga kerja yang relatif murah.

Pada praktiknya terdapat unsurunsur yang membuat perjanjian nominee tersebut tidak diperbolehkan dibuat karena dianggap sebagai perbuatan melawan hukum, Perbuatan melawan hukum berdasarkan Pasal 1365 Kitab Undang-Undang Hukum Perdata (KUHPerdata) dapat disimpulkan bahwa suatu perbuatan dikatakan melawan hukum jika terpenuhinya unsur-unsur sebagai berikut :

1) ada perbuatan melawan hukum;

2) ada kesalahan;

3) ada hubungan sebab akibat antara

kerugian dan perbuatan;

4) ada kerugian yang ditimbulkan

Dari unsur-unsur perbuatan melawan hukum diatas maka perjanjian nominee yang sebenarnya dikatakan sebagai perbuatan melawan hukum apabila isi dari perjanjian nominee tersebut memenuhi keempat unsur diatas, di Indonesia khususnya perjanjian nominee sering digunakan sebagai penyelundupan hukum kepemilikan tanah, kepemilikan saham, dan juga kepemilikan harta benda lainnya dengan didasari oleh Kuasa mutlak yang dibuat berdampingan dengan nominee tersebut, yang pada isi perjanjian tersebut jelas melanggar pengaturan perjanjian pada umumnya yang telah diatur secara sedemikian rupa. Selain kuasa mutlak terdapat beberapa akta yang mendasari perjanjian nominee tersebut agar dapat digunakan untuk perbuatan yang merugikan para pihak maupun merugikan negara, karena perjanjian nominee dapat dibuat untuk suatu penggelapan pajak atau untuk mempermudah Orang Asing menguasai segala bentuk kepemilikannya di Indonesia.

Akta Notaris merupakan perjanjian para pihak yang mengikat mereka yang membuatnya, karena itu syarat-syarat sahnya suatu perjanjian harus dipenuhi (Pasal 1320 KUH Perdata). Dalam hukum perjanjian ada akibat hukum tertentu jika syarat subjektif dan syarat objektif tidak dipenuhi. Jika syarat subyektif tidak terpenuhi, maka perjanjian dapat dibatalkan (vernietigbaar) sepanjang ada permintaan oleh orang tertentu atau yang berkepentingan. Jika syarat objektif tidak dipenuhi, maka perjanjian batal demi hukum (nietig), tanpa perlu ada permintaan dari para pihak, dengan demikian perjanjian dianggap tidak pernah ada dan tidak mengikat siapapun.

Pada dasarnya dalam pembuatan akta Notaris hanyalah mengkonstatir kehendak para pihak, berdasarkan wewenang yang ada pada Notaris sebagaimana tersebut dalam Pasal 15 UUJN dan kekuatan pembuktian dari akta Notaris, maka ada 2 (dua) pemahaman, yaitu :

a. Tugas jabatan Notaris adalah memformulasikan keinginan/tindakan para pihak ke dalam akta otentik, dengan memperhatikan aturan hukum yang berlaku.

b. Akta Notaris sebagai akta otentik mempunyai kekuatan pembuktian yang sempurna, sehingga tidak perlu dibuktikan atau ditambah dengan alat bukti lainnya, jika ada orang/pihak yang menilai atau menyatakan bahwa akta tersebut tidak benar.

Walaupun Notaris hanya mengikuti kehendak dari para pihak Notaris juga memilikilarangandanketidakwenangan Notaris untuk membuat akta, Pasal 52 ayat (1) dan Pasal 53 UUJN menegaskan dalam keadaan tertentu Notaris dilarang membuat akta, larangan ini hanya ada pada subjek hukum para penghadap, jika subjek hukumnya dilarang, maka substansi akta (perbuatannya) apapun tidak diperkenankan untuk dibuat. ${ }^{9}$

Tugas dan kewajiban yang didasari oleh kewenangan yang sah, baik yang bersumber pada undang-

\footnotetext{
${ }^{9}$ Habib Adjie, Op.Cit, 2008, hlm.156
} 
undang maupun dari perjanjian dapat menimbulkan tanggung jawab pada pelaksana kewajiban karena setiap kewenangan yang diberikan pasti selalu di ikuti oleh kewajiban ataupun tanggung jawab. Notaris diberikan kewenangan dalam suatu pembuatan akta otentik, oleh karenaitu notaris yang bersangkutan berkewajiban memenuhi segalapersyaratanyangtelahditentukan, konsekuensi yang timbul bagi notaris sebagai pejabat umum yang diberikan kewenangan dalam pembuatan akta otentik,makaiaharusbertanggungjawab dan apabila terjadi pelanggaran atau penyimpanganterhadappembuatanakta yang dibuatnya, akta yang dibuat oleh notaristersebutjugaberakibattidaksah. ${ }^{10}$ Pihakataumerekayangmerasadirugikan oleh tindakan Notaris di luar wewenang tersebut, maka Notaris dapat digugat secara perdata ke Pengadilan Negeri bahkan Notaris dapat dituntut secara pidana dalam pertanggungjawabannya. Akibat dari notaris yang membuat perjanjian yang dilarang dalam Pasal 33 ayat (1) UUPM dan melanggar Asas Nasionalitas yang Terkandung dalam UUPA, maka notaris telah melanggar 2 (dua) peraturan, yaitu UUJN dan Kode Etik Notaris, sebagai berikut :

1) Pelanggaran terhadap UUJN

(a)Pasal 4 ayat (2) yaitu sumpah/ janji jabatan notaris Notaris wajib mengucapkan sumpah/ janji di hadapan Menteri Hukum dan Hak Asasi Manusia sebelum menjalankan jabatannya. Dalam sumpah/ janji jabatan notaris tersebut, ketika diambil sumpahnya notaris mengucapkan "bahwa saya akan patuh dan setia kepada Negara Republik Indonesia, Pancasila dan Undang-Undang Dasar Negara Republik

${ }^{10}$ Sjaifurrachman, Aspek Pertanggungjawaban Notaris Dalam Pembuatan Akta, CV. Mandar Maju, Bandung, 2011. hlm.17
Indonesia tahun 1945, Undangundang tentang Jabatan notaris serta peraturan perundang-undangan lainnya".

(b)Pasal 15 ayat (2) huruf e yang menetapkan kewajiban untuk: "Memberikan penyuluhan hukum sehubungan dengan pembuatan akta".

(c)Pasal 16 ayat (1) huruf a yaitu: "Bertindak amanah, jujur, saksama, mandiri, tidak berpihak, dan menjaga kepentingan pihak yang terkait dalam perbuatan hukum".

(d)Pasal 16 ayat (1) huruf e yaitu: "Memberikan pelayanan sesuai dengan ketentuan dalam undangundang ini, kecuali ada alasan untuk menolaknya".

Notaris bisa menolak para pihak yang datang kepadanya yang meminta dibuatkan akta dimana akta tersebut bertentangan dengan undang-undang. Dalam praktek juga ditemukan alasanalasan lain sehingga notaris menolak memberikan jasanya. Salah satunya adalah apabila karena pemberian jasa tersebut, Notaris melanggar sumpahnya atau melakukan perbuatan melanggar hukum. ${ }^{11}$

1) Pelanggaran Terhadap Kode Etik Notaris pasal yang dilanggar dalam kode etik adalah Pasal 3 angka 4 yaitu: "Bertindak jujur, mandiri, tidak berpihak, penuh rasa tanggung jawab, berdasarkan peraturan perundangundangan dan isi sumpah jabatan Notaris".

Apabila notaris melakukan pelanggaran atas ketentuanketentuan sebagaimana tersebut di atas maka notaris dapat dikenakan sanksi sebagaimana dimaksud dalam Pasal 16 ayat (11) UUJN. Selain itu

${ }^{11}$ Soegondo Notodisoerjo, Hukum Notariat di Indonesia, Suatu Penjelasan, Rajawali, Jakarta, 1982, hlm.98. 
Dewan Kehormatan Ikatan Notaris Indonesia juga dapat menjatuhkan sanksi sebagaimana disebutkan dalam Pasal 6 ayat (1) Kode Etik Notaris.

Notaris selaku pejabat umum dituntut untuk bekerja secara professional dengan menguasai selukbeluk profesinya menjalankan tugasnya, notaris harus menyadari kewajibannya bekerja mandiri, jujur, tidak memihak, dan penuh rasa tanggung jawab serta secara profesional. ${ }^{12}$

Dalam prakteknya masih ditemui Notaris dalam membuat akta tanpa mengindahkan peraturan PerundangUndangan yakni pembuatan akta perjanjian sebagai back up akta nominee saham dalam perusahaan penanamanan modal salah satunya yaitu akta perjanjian/pernyataan nominee (nominee agreement/statement). Pembuatanaktatersebuttelahmelanggar Pasal 33 ayat (1) UUPM dan juga pembuatan akta nominee dalam bidang pertanahan dengan mencederai Asas Nasionalitas dalam UUPA juga jelas melanggar ketentuan pemilikan Hak Atas Tanah yang dimiliki oleh Orang Asing hanyalah Hak Pakai.

Apabila notaris tetap membuatkan akta Nominee yang mengandung perbuatan melawan hukum tersebut, maka akibatnya adalah perjanjian dan/ atau pernyataan itu dinyatakan batal demi hukum. Sebagai notaris harus memahami larangan tersebut agar nantinya tidak merugikan pihak lain maupun Notaris itu sendiri.

\section{Tanggung jawab Notaris Secara} perdata, Notaris dapat dimintakan pertanggungjawaban perdata berupa tuntutan ganti kerugian oleh para pihak yang merasa dirugikan atas

${ }^{12}$ C.S.T. Kansil \& Christine S.T. Kansil, Modul Hukum Perdata Termasuk Asas- Asas Hukum Perdata, Cet III, PT Pradnya Paramita, Jakarta, 2000, hlm. 87-88 perbuatan melawan hukum yang dilakukannya.

2. Tanggung Jawab Notaris secara pidana, Notaris dapat dimintakan pertanggungjawabandengandituntut pasal penipuan dan pemalsuan terhadap akta yang dibuat oleh Notaris.

3. Tanggung jawab Notaris secara administratif, akibatdaripembuatan akta nominee yang dikategorikan sebagai perbuatan melawan hukum maka notaris dapat dikenai sanksi administratif sampai pada pemberhentian secara tidak hormat.

\section{Konstruksi Hukum Untuk Menang- gulangi Perbuatan Melawan Hukum Dalam Akta Nominee Yang Dibuat Notaris}

Indonesia merupakan Negara Hukum, maka sesuai dengan Teori Negara Hukum yang digunakan sebagai pisau analisa dalam penulisan ini, Prinsip yang terpenting dalam Negara Hukum adalah perlindungan yang sama (equal protection) atau persamaan dalam hukum (equality before the law). Menurut Dicey, "Bahwa berlakunya Konsep kesetaraan di hadapan hukum (equality before the law), di mana semua orang harus tunduk kepada hukum, dan tidak seorang pun berada di atas hukum (above the law) karena tidak adanya pengaturan yang mengatur mengenai nominee maupun pengaturan pelarangan pembuatan nominee maka penulis bermaksud untuk mengkonstruksikan hukum bagi kasus perjanjian nominee.

Teori Sistem Hukum Menurut Lawrence Meir Friedman, seorang ahli sosiologi hukum dari Stanford University, ia mengemukakan bahwa efektif dan berhasil tidaknya penegakan hukum tergantung tiga unsur sistem hukum, yakni struktur hukum (struktur oflaw), substansi hukum (substance of the law) dan budaya 
hukum (legal culture). ${ }^{13}$ Struktur hukum menyangkut aparat penegak hukum, substansi hukum meliputi perangkat perundang-undangan dan budaya hukum merupakan hukum yang hidup (living law) yang dianut dalam suatu masyarakat. Untuk mengkonstruksikan pengaturan mengenai Perjanjian Nominee maka unsur sistem hukum tersebut harus terpenuhi dan diperbaiki.

\section{Struktur Hukum (Legal Structure)}

Struktur adalah Pola yang menunjukkan tentang bagaimana hukum dijalankan menurut ketentuanketentuan formalnya. Struktur ini menunjukkan bagaimana pengadilan, pembuat hukum dan badan serta proses hukum itu berjalan dan dijalankan.

Dalam teori Lawrence Meir Friedman hal ini disebut sebagai sistem Struktural yang menentukan bisa atau tidaknyahukumitudilaksanakandengan baik. Struktur hukum berdasarkan UU No. 8 Tahun 1981 meliputi; mulai dari Kepolisian, Kejaksaan, Pengadilan dan Badan Pelaksana Pidana (Lapas).

Kewenangan lembaga penegak hukum dijamin oleh Undang-Undang. Sehingga dalam melaksanakan tugas dan tanggung jawabnya tidak terlepas dari pengaruh kekuasaan pemerintah dan pengaruh-pengaruh lainnya.

Khusus untuk perjanjian nominee untuk mengkonstruksikan struktur dalam perjanjian nominee harus dirumuskan pengaturannya, penegasan dan pemberian sanksi oleh aparat penegak hukum, dalam dunia Notaris seperti Majelas Pengawas Daerah, Majelis Pengawas Wilayah sampai pada Majelis Pengawas Nasional maka harus adanya kordinasi yang lebih baik antara aparatpenegakhukum, karenadalam hal ini aparat penegak hukum dalam dunia

${ }^{13}$ M. Friedman, Lawrence, The Legal System. A Social Science Perspective, Russel Sage Foundation, New York, 1986, hlm.17.
Notaris sudah cukup jelas adanya maka harus dilihat pelaksanaannya.

\section{Isi Hukum / Substansi Hukum (Legal} Substance)

Dalam teori Lawrence Meir Friedman hal ini disebut sebagai sistem substansial yang menentukan bisa atau tidaknya hukum itu dilaksanakan, substansi juga berarti produk yang dihasilkan oleh orang yang berada dalam sistemhukumyangmencakupkeputusan yangmerekakeluarkan, aturanbaruyang mereka susun. Substansi juga mencakup hukum yang hidup (living law), bukan hanya aturan yang ada dalam kitab undang-undang (law books). Berikut beberapa peraturan yang berkaitan dengan pembahasan penulisan ini yang harus dikonstruksikan berdasarkan substansi :

a.KitabUndang-UndangHukumPerdata (KUHPerdata)

Pengaturan mengenai perjanjian ini memiliki substansial tersendiri untuk menjalankan perjanjian tersebut, melihat dari telahdiaturnyaperjanjiansecarajelas maka menurut penulis perjanjian nominee tidak termasuk telah memenuhi ketentuan yang telah ditetapkan, maka dari itu perlunya dibentuk sebuah substansi yang lebih baik agar perjanjian nominee tidak mencederai asas-asas yang terkandung dalam perjanjian, karena pada dasarnya perjanjian nominee dapat dibuat namun melihat pada isi dan tujuan dari perjanjian tersebut.

$$
\text { Perjanjian nominee }
$$

tidak diatur secara tegas dalam pengaturan hukum di Indonesia, perjanjian nominee pada dasarnya tidak dikenal dalam sistem hukum Eropa Kontinental yang berlaku di Indonesia. Perjanjian nominee pada awalnya hanya terdapat pada sistem hukum Common Law. namun seiring dengan semakin berkembangnya 
zaman Perjanjian Nominee ini telah tumbuh dan berkembang dalam masyarakat dikarenakan kebutuhan masyarakat, sebagaimana yang telah dijelaskan, substansi hukum tidak hanya terdiri atas pengaturan yang telah diatur secara jelas dalam Undang-Undang namun juga terhadap hukum yang timbul atas dasar kebutuhan masyarakat.

b. Undang-Undang Nomor 5 Tahun 1960 tentang Peraturan Dasar PokokPokok AgrariaPokok Agraria(UUPA)

Perjanjian nominee di bidang pertanahan dalam praktek adalah memberikan kemungkinan bagi warga negara asing memiliki tanah yang dilarang UUPA adalah dengan jalan "Meminjam nama (nominee)" warga negara Indonesia dalam melakukan jual beli, sehingga secara yuridis formal tidak menyalahi peraturan Pasal 26 ayat (2) UUPA, namun perjanjian nominee tersebut secaratidaklangsungmencederaiasas nasionalitas yang terkandung dalam UUPA.

Dengan melihat adanya perjanjian nominee yang dapat merugikan WNI bahkan merugikan negara dikarenakan pemilikan tanah olehOrangAsingdapatterjadimelalui akta nominee tersebut maka haruslah dibuatkan mengenai pelarangan atau pembatasan lebih lagi terhadap Orang Asing secara tegas, karena Perjanjian Nominee dalam bidang pertanahan ini substansinya sangat menyalahi aturan dalam UUPA, dan jika diperlukan harus adanya sanksi yang tegas diberikan kepada para pelaku nominee.

c. Undang-Undang Nomor 25 Tahun 2007 tentang Penanaman Modal

Sama halnya dengan nominee yang terjadi pada penanaman modal yang diatur dalam Pasal 33 ayat (1) dan (2) UUPM telah jelas melarang adanya nominee dalam hal kepemilikan saham, pelarangan terhadap penanam modal dalam negeri dan penanam modal asing untuk membuat perjanjian dan/ atau pernyataan yang menegaskan bahwa kepemilikan saham dalam perseroan terbatas untuk dan atas nama orang lain. Pasal 33 ayat (2) UUPM selanjutnya mengatur bahwa perjanjian semacam itu dinyatakan batal demi hukum.

Khususnya ketentuan Pasal 33 ayat(1) dan ayat (2)UUPM, penanam modal dalam negeri dan penanam modal asing dilarang membuat perjanjian dan/atau pernyataan yang menegaskan bahwa kepemilikan saham dalam perseroan terbatas untuk dan atas nama orang lain. Jika ada perjanjian semacam itu, maka perjanjian tersebut dinyatakan batal demihukum.Jadi, tidak ada carayang sahuntukbisamenjaminsipemegang saham yang namanya dipinjam akan menjual kembali sahamnya kepada pemegang saham (penanam modal) yang sebenarnya.

Berdasarkan pengaturan diatas dalam hal ini jelas bahwa pelarangannominee telah diatur tidak diperbolehkan untuk dilakukan, maka dari itu karena masih adanya beberapa penyelundupan mengenai nominee dalam bidang penanaman modal ini maka diperlukannya sanksi yang lebih tegas terhadap substansi pengaturan hukumnya agar lebih memberikan efek jera dan pengaturantersebutdapatdijalankan dan berjalan dengan baik.

d. Undang-Undang Nomor 2 Tahun 2014tentangPerubahanAtasUndangUndang Jabatan Notaris

Akta Notaris merupakan perjanjian para pihak yang mengikat mereka membuatnya, karena itu syarat-syaratsahnyasuatuperjanjian 
harus dipenuhi (Pasal $1320 \mathrm{KUH}$ Perdata). Dalam hukum perjanjian ada akibathukum tertentujika syarat subjektif dan syarat objektif tidak dipenuhi. Jika syarat subyektif tidak terpenuhi, maka perjanjian tersebut dapat dibatalkan atau batal demi hukum.

Mengenai larangan dan ketidakwenangan Notaris untuk membuat akta, Pasal 52 ayat (1) dan Pasal 53 UUJN menegaskan dalam keadaan tertentu Notaris dilarang membuatakta,laranganinihanyaada pada subjek hukum para penghadap, jika subjek hukumnya dilarang, maka substansi akta (perbuatannya) apapun tidak diperkenankan untuk dibuat. ${ }^{14}$

Dari peraturan tersebut maka diperlukannyakejelasannormaterhadap akta yang diperbolehkan atau tidak boleh dibuat oleh Notaris mengacu pada kewajiban Notaris untuk melayani masyarakat, untuk melindungi notaris agar tidak terjerumus dan tidak terlibat terhadap perbuatan para pihak yang melanggar hukum, maka harusnya ada pelarangansecarajelasdantegasterhadap Notaris.

\section{Budaya Hukum (Legal Culture)}

Kultur hukum menyangkut budaya hukum yang merupakan sikap manusia (termasukbudayahukumaparatpenegak hukumnya) terhadap hukum dan sistem hukum. Sebaik apapun penataan struktur hukum untuk menjalankan aturan hukum yang ditetapkan dan sebaik apapun kualitas substansi hukum yang dibuat tanpa didukung budaya hukum oleh orang-orang yang terlibat dalam sistem dan masyarakat maka menegakkan hukum tidak akan berjalan secara efektif.

Kultur/Budaya hukum menurut Lawrence Meir Friedman adalah sikap

${ }^{14}$ Habib Adjie, Hukum Notaris Indonesia, Refika Aditama, Bandung, 2008, hlm.156 manusia terhadap hukum dan sistem hukum-kepercayaan, nilai, pemikiran, serta harapannya. ${ }^{15}$ Kultur/budaya hukum adalah suasana pemikiran sosial dan kekuatan sosial yang menentukan bagaimanahukumdigunakan, dihindari, ataudisalahgunakan.Budayahukumerat kaitannya dengan kesadaran hukum masyarakat.

Semakin tinggi kesadaran hukum masyarakat maka akan tercipta budaya hukum yang baik dan dapat merubah pola pikir masyarakat mengenai hukum selama ini. Secara sederhana, tingkat kepatuhan masyarakat terhadap hukum merupakan salah satu indikator berfungsi-nya hukum. Perjanjian nomineemerupakanketentuanatausalah satu macam perjanjian yang tidak diatur dalam KUHPerdata maupun pengaturan lain mengenai perjanjian lainnya.

Perjanjian ini tumbuh dan berkembang dalam kehidupan masyarakatterutamadalambidangbisnis dan juga Orang Asing dalam berbisnis di Indonesia, melihatdaripengertiankultur di atas maka jenis perjanjian nominee ini merupakan perjanjian yang lahir akibatdaripengaruhbudaya masyarakat, perjanjian ini pula dapat berjalan karena didukung oleh masyarakat yang terkadang diikuti dukungan dari pejabat-pejabat yang dapat melancarkan perjanjian nominee ini dapat terlaksana. Melihat perjanjian nominee ini yang tumbuh dan melekat pada budaya masyarakat maka haruslah adanya kesadaran masyarakat yang sangat tinggi mengenai perjanjian nominee ini, kesadaran tersebut haruslah berangkat dari adanya pemahaman yang baik mengenai nominee itu sendiri, maka dari budayainidapatdilakukannyasosialisasi kepada masyarakat agar tetap tidak mengakibatkankerugianbagiparapihak, maka dari itu konstruksi hukum yang diharapkan untuk perjanjian nominee

\footnotetext{
${ }^{15}$ M. Friedman, Lawrence, Op.Cit, hlm.8
} 
ini dilakukan dengan menggunakan dan disesuaikan dengan Budaya Hukum yang ada diIndonesia, agar Warga Negara Indonesia tetap terlindungi dan tidak dirugikan dengan adanya dan dibuatnya perjanjian nominee ini.

\section{SIMPULAN}

Berdasarkan uraian dan analisa yang dilakukan, maka penulis menarik kesimpulan sebagai berikut:

1. Notaris diberikan kewenangan dalam suatu pembuatan akta otentik, sebagai pejabat umum yang diberikan kewenangan dalam pembuatan akta otentik, maka ia harus bertanggung jawab atas akta yang dibuatnya. Pihak atau mereka yang merasa dirugikan oleh tindakan Notaris di luar wewenang tersebut, sehingga Notaris dapat dimintakan pertanggung jawaban sebagai berikut :

a. Tanggung jawab Notaris Secara perdata, Notaris dapat dimintakan pertanggungjawaban perdata berupa tuntutan ganti kerugian

b. Tanggung Jawab Notaris secara pidana, Notaris dapat dimintakan pertanggungjawabandengandituntut pasal penipuan dan pemalsuan terhadap akta yang dibuat oleh Notaris.

c. Tanggung jawab Notaris secara administratif, notaris dapat dikenai sanksi administratif sampai pada pemberhentian secara tidak hormat.

2. Dalam mengkonstruksikan Perjanjian Nominee dalam penulisan ini, penulis menggunakan Teori berdasarkan Lawrence M. Friedman yaitu sebagai berikut :

\section{a. Struktur Hukum (Legal Structure)}

Karena suatu sistem tidak akan berjalan dengan baik jika tidak ada penegak hukum yang kredibilitas, maka dari itu aparat penegak hukum dalam hal ini khususnya kepada Dewan Majelas Pengawas Notaris, serta seluruh aparat penegak hukum memperbaiki sistem keamanan dan memberikan sanksi.

b. substansi hukum (substance of the law) darisegalaaturanyangberkaitan dengan nominee maka padabagian isi/ substansi ini harus adanya kejelasan norma, adanya pelarangan terhadap nominee yang merupakan perbuatan melawan hukum, dan juga adanya sanksi yang tegas.

c. Budaya hukum, konstruksi hukum yang diharapkan untuk perjanjian nominee ini dilakukan dengan menggunakan dan disesuaikan dengan Budaya Hukum yang ada di Indonesia maka harus lebih menekankan kepada kesadaran masyarakat dan juga jika perlu dilaksanakannyasosialisasimengenai nominee ini.

Penulis berharap bahwa sebagai Pejabat Umum, Notaris harus lebih menerapkan prinsip kehati-hatian dalam menangani para penghadap yang hendak dimintakan membuat akta, Notaris juga seharusnya lebih dapat bersikap tegas untuk dapat memillah dan menolak membuat akta apabila akta tersebut berindikasi perbuatan melawan hukum atau melanggar ketentuan Undangundang yang dapat merugikan para pihak, negara bahkan Notaris itu sendiri.

Penulis juga memberikan saran kepada Presiden dan DPR RI sebagai bagian dari pemerintah yang berwenang membuat Undang-Undang dapat juga merombak UUPA tentang pembatasan hak atas tanah terhadap Orang Asing yang lebih dipersempit kembali, mengkonstruksikan Hukum yang baru terhadap pelarangan Nominee lebih tegas dan terang dalam bentuk aturan dan juga melakukan denda terhadap pelaku yang telah terlanjur melakukannya, pemerintah juga dihimbau bekerja sama dengan aparat penegak hukum lain agar hukum dapat dilaksanakan dengan baik maka selalu 
melakukan pemeriksaan terhadap segala transaksi yang mengatasnamakan orang lain.

\section{DAFTAR PUSTAKA}

\section{Buku}

Fuady Munir, 2002, Perbuatan Melawan Hukum: Pendekatan Kontemporer, PT. Citra Aditya Bakti, Bandung Garner, Bryant A., 1999, Black's Law Dictionnary With Guide To Pronunciation. St. Paul: West Publishing.Habib Adjie, 2008, Hukum Notaris Indonesia, Refika Aditama, Bandung. Hartono Hadi Soepapto, 1984, Pokok-pokok Perikatan dan Hukum Jaminan, Liberty, YogyakartaM. Friedman, Lawrence, 1986, The Legal System. A Social Science Perspective, Russel Sage Foundation, New York. Martin Roestami, 2011. Konsep-konsep Hukum Kepemilikan Properti Bagi Asing (dihubungkan dengan hukum pertanahan), Alumni, Bandung.Ridwan Syahran, 2000, Seluk Beluk dan Asas-asas Hukum Perdata, Alumni, Bandung.

Sjaifurrachman, 2011. Aspek Pertanggungjawaban Notaris Dalam Pembuatan Akta, CV. Mandar Maju, Bandung.

Sri Adiningsih, 2008. Satu Dekade Pasca-Krisis Indonesia: Badai Pasti Berlalu, Kanisius, Jakarta. Supriadi, 2006. Etika dan Tanggung Jawab Profesi Hukum di Indonesia, Sinar Grafika, Jakarta.

Wirjono Prodjodikoro, 1988. Azas-azas Hukum Perdata, Bale Bandung, Bandung.

\section{Jurnal}

M. Yazid Fathoni, Konsep Keadilan Dalam Pengelolaan dan Pemanfaatan Sumber Daya Alam Menurut
Undang-Undang Pokok Agraria Tahun 1960, Jurnal IUS (Hukum dan Keadilan), Vol. I, No. 1, Edisi April 2013, http://jurnalius.ac.id/ ojs/index.php/jurnalIUS/article/ view/225/197, diakses tanggal 6 April 2018 